\title{
Comparison of AFLP and rep-PCR genomic fingerprinting with DNA-DNA homology studies: Xanthomonas as a model system
}

\author{
Jan L. W. Rademaker, ${ }^{1} \dagger$ Bart Hoste, ${ }^{5}$ Frank J. Louws, ${ }^{1,3,4}$ \\ Karel Kersters, ${ }^{6}$ Jean Swings, ${ }^{5,6}$ Luc Vauterin, $^{7}$ Paul Vauterin ${ }^{7}$ \\ and Frans J. de Bruijn ${ }^{1,2,3}$
}
1,2,3 MSU-DOE Plant
Research Laboratory ${ }^{1}$
Department of
Microbiology ${ }^{2}$ and NSF
Center for Microbial
Ecology 3 , Michigan State
University, East Lansing,
Michigan 48824, USA
4 Department of Plant
Pathology, North
Carolina State
University, Raleigh,
North Carolina 27695,
USA
5,6 BCCM/LMG Bacteria
Collection ${ }^{5}$ and
Laboratorium voor
Microbiologie6,
Rijksuniversiteit Gent, Ledeganckstraat 35, B-9000 Ghent, Belgium
7 Applied Maths BVBA, Derbystraat 331, B-9051
Ghent, Belgium

\author{
Author for correspondence: Frans de Bruijn. Tel: +1 517353 2229. Fax: + 15173539168. \\ e-mail:debruijn@pilot.msu.edu
}

The genus Xanthomonas contains a large number of strains, which have been characterized by a variety of phenotypic and genotypic classification methods. The Xanthomonas collection constitutes one of the largest groups of bacteria that have been characterized phylogenetically by DNA-DNA homology studies and genomic fingerprinting. Presently, a total genomic DNA-DNA homology value of $\mathbf{7 0} \%$ represents an internationally accepted criterion to define bacterial species levels. However, the complexity of DNA-DNA reassociation kinetics methods precludes the rapid analysis of large numbers of bacterial isolates, which is imperative for molecular microbial diversity studies. Therefore, the aim of this study was to compare more facile PCR-based genomic fingerprinting techniques, such as repetitive-sequence-based (rep)PCR and AFLP genomic fingerprinting, to DNA-DNA hybridization studies. Using three different primer sets, rep-PCR genomic fingerprint patterns were generated for 178 Xanthomonas strains, belonging to all 20 previously defined DNA-DNA homology groups, and one Stenotrophomonas maltophilia strain. In addition, AFLP genomic fingerprints were produced for a subset of $\mathbf{8 0}$ Xanthomonas strains belonging to the 20 DNA-DNA homology groups and for the S. maltophilia strain. Similarity values derived from rep-PCR- and AFLPgenerated fingerprinting analyses were calculated and used to determine the correlation between rep-PCR- or AFLP-derived relationships and DNA-DNA homology values. A high correlation was observed, suggesting that genomic fingerprinting techniques truly reveal genotypic and phylogenetic relationships of organisms. On the basis of these studies, we propose that genomic fingerprinting techniques such as rep-PCR and AFLP can be used as rapid, highly discriminatory screening techniques to determine the taxonomic diversity and phylogenetic structure of bacterial populations.

Keywords: rep-PCR, AFLP, Xanthomonas, DNA-DNA homology studies, molecular phylogeny

†Present address: The Netherlands Culture Collection of Bacteria (NCCB), PO Box 80056, 3508 TB Utrecht, The Netherlands.

Abbreviations: ARDRA, amplified rDNA restriction enzyme analysis; BER, individual BOX-, ERIC- and REP-PCR generated genomic fingerprints combined linearly using the 'combined gel' option of the GELCOMPAR program (BER profile); BOX-PCR, PCR based on primers targeting the highly conserved repetitive DNA sequences of the BOXA subunit of the BOX element of Streptococcus pneumoniae; DAF, DNA amplification fingerprinting; ERIC, enterobacterial repetitive intergenic consensus; RAPD, random amplified polymorphic DNA; rep-PCR, repetitive-sequence-based PCR; REP, repetitive extragenic palindromic sequence; UPGMA, unweighted pair group method using averages. 
Table 1. DNA-DNA homology groups and strains analysed by AFLP and rep-PCR genomic fingerprinting

\begin{tabular}{|c|c|c|c|}
\hline Taxon & Host & Geographical origin & LMG strain no.* \\
\hline \multicolumn{4}{|l|}{ Group 1} \\
\hline$X$. fragariae & Fragaria ananassa & Greece, USA & $706,708^{T}$ \\
\hline \multicolumn{4}{|l|}{ Group 2} \\
\hline X. hortorum pv. hederae & Hedera helix & USA & $733 \dagger$ \\
\hline$X . h$. pelargonii & Pelargonium sp. & New Zealand, France, Belgium & $7314 \dagger, \mathbf{7 3 5 6}, \mathbf{7 5 8 5}, 7712$ \\
\hline$X . h$. vitians & Lactuca sativa & Zimbabwe & 938 \\
\hline \multicolumn{4}{|l|}{ Group 3} \\
\hline$X$. populi & Populus canadensis & France & $\mathbf{9 7 4}, \mathbf{5 7 4 3}^{\mathrm{T}}, 5753$ \\
\hline \multicolumn{4}{|l|}{ Group 4} \\
\hline X. arboricola corylina & Corylus sp. & UK, USA & $688,689 \dagger, 8658,8660$ \\
\hline$X$. a. juglandis & Juglans regia & $\begin{array}{l}\text { New Zealand, The } \\
\text { Netherlands }\end{array}$ & $747 \dagger, 8047$ \\
\hline X. a. poinsettiicola & Euphorbia pulcherrima & New Zealand & 5403 \\
\hline X. a.populi & Populus euramericana & The Netherlands & $12141 \dagger$ \\
\hline$X$. a.pruni & Prunus sp. & New Zealand & $852 \uparrow, 8680$ \\
\hline \multicolumn{4}{|l|}{ Group 5} \\
\hline$X$. cassavae & Manihot esculenta & Malawi, Rwanda & $670,673 \dagger, 5264$ \\
\hline \multicolumn{4}{|l|}{ Group 6} \\
\hline$X$. codiaei & Codiaeum variegatum & USA & 8677,8678 \\
\hline \multicolumn{4}{|l|}{ Group 7} \\
\hline X. bromi & Bromus sp. & France, New Zealand & (947), 8269, 8272 \\
\hline \multicolumn{4}{|l|}{ Group 8} \\
\hline X. cucurbitae & Cucurbita maxima & New Zealand & $690 \dagger, 8662$ \\
\hline \multicolumn{4}{|l|}{ Group 9} \\
\hline $\begin{array}{l}X \text {. axonopoals alfalfae } \\
X .9 x+n o n o d i s\end{array}$ & Medicago sativa & Australia, Sudan & $\begin{array}{l}497 \dagger, 8079 \\
\mathbf{5 3 9}^{\mathrm{T}} 530\end{array}$ \\
\hline $\begin{array}{l}X . \text { a. axonopodls } \\
X . \text { a. bauhiniae }\end{array}$ & $\begin{array}{l}\text { Axonopus scoparius } \\
\text { Bauhinia racemosa }\end{array}$ & $\begin{array}{l}\text { Colombia } \\
\text { India }\end{array}$ & $\begin{array}{l}\mathbf{5 3 8}^{\mathrm{T}}, 539 \\
548\end{array}$ \\
\hline & $\begin{array}{l}\text { Bauhinia racemosa } \\
\text { Begonia } \text { sp. }\end{array}$ & $\begin{array}{l}\text { India } \\
\text { Belgium, New Zealand, UK }\end{array}$ & $\begin{array}{l}548 \\
\mathbf{5 5 1}, 7178,7188,7226, \mathbf{7 3 0 3} \dagger,\end{array}$ \\
\hline & & & 7304,7601 \\
\hline X. a. cajani & Cajanus cajan & India, Sudan & $558 \dagger, 7387 \mathrm{t} 1$ \\
\hline X. a. cassavae & Manihot esculenta & Niger & 8049 \\
\hline$X$. a. cassiae & Cassia tora & India & $675 \dagger$ \\
\hline$X . \operatorname{a.citri}(\mathrm{A})$ & $\begin{array}{l}\text { Citrus aurantifolia, C. latifolia, } \\
\text { C. limon, C. reticulata }\end{array}$ & $\begin{array}{l}\text { Brazil, India, New Zealand, } \\
\text { Pakistan, USA }\end{array}$ & $\begin{array}{l}\text { 681, (682†), 8650, 8654, 8657, } \\
9176,9321,9665,9671\end{array}$ \\
\hline$X . a$. aurantifolii (citri B) & Citrus limon & Argentina & 9179,9183 \\
\hline$X$. a. aurantifolii (citri C) & Citrus aurantifolia & Brazil & $8655,9181,9658$ \\
\hline$X$. a. aurantifolii (citri $\mathrm{D})$ & Citrus aurantifolia & Mexico & 9182 \\
\hline$X$. a. citrumelo $($ citri $\mathrm{E})$ & $\begin{array}{l}\text { Poncirus trifoliata } \times \text { Citrus } \\
\text { sinensis, Citrus paradisi }\end{array}$ & USA & $9160,9167,9172,9175,9325$ \\
\hline$X$. a. clitoriae & Clitoria biflora & India & $9045 \dagger$ \\
\hline$X$. a. coracanae & Eleusine coracana & India & $686 \uparrow, 7476$ \\
\hline X. a. cyamopsidis & Cyamopsis tetragonolobus & India & $691 \dagger$ \\
\hline$X$. a. desmodii & Desmodium dichotomum & India & $692 \dagger$ \\
\hline$X$. a. desmodiigangetici & Desmodium gangeticum & India & $693 \dagger$ \\
\hline X. a. desmodiilaxiflori & Desmodium laxiflorum & India & $9046 \dagger$ \\
\hline$X . a$. desmodiirotundifolii & Desmodium styracifolium & India & $694 \dagger$ \\
\hline X. a. dieffenbachiae & $\begin{array}{l}\text { Anthurium sp., Dieffenbachia } \\
\text { sp. }\end{array}$ & Brazil, USA & $695 \dagger, 7399,8664$ \\
\hline$X$. a. erythrinae & Erythrina variegata & India & $698 \dagger$ \\
\hline$X$. a. glycines & Glycine max & Sudan & $712 \dagger$ \\
\hline X. a. lespedezae & Lespedeza sp. & USA & $757 \dagger$ \\
\hline X. a. malvacearum & Gossypium sp. & Sudan, Uganda & $\mathbf{7 6 1} \uparrow, 7429$ \\
\hline X. a. manihotis & Manihot esculenta & Brazil, Nigeria & $771,773 \dagger, 778,784 \dagger$ \\
\hline$X$. a. patelii & Crotalaria juncea & India & $811 \dagger$ \\
\hline$X$. a. phaseoli & Phaseolus vulgaris & Romania & $7455 \dagger, 8014$ \\
\hline X. a. phaseoli var. fuscans & Phaseolus vulgaris & Germany, South Africa, USA & $\mathbf{8 3 7 t 1}, 7511,8036$ \\
\hline X. a. phyllanthi & Phyllanthus niruri & Sudan & $844 \dagger$ \\
\hline X. a. poinsettiicola & Euphorbia pulcherrima & India & $849 \dagger$ \\
\hline X. a. rhynchosiae & Rhynchosia memnonia & Sudan & $8021 \dagger$ \\
\hline$X$. a. ricini & Ricinus communis & $\begin{array}{l}\text { Ethiopia, Hong Kong, India, } \\
\text { Zimbabwe }\end{array}$ & $861 \dagger, 862,7441,7443$ \\
\hline
\end{tabular}


Table 1 (cont.)

\begin{tabular}{|c|c|c|c|}
\hline Taxon & Host & Geographical origin & LMG strain no.* \\
\hline X. a. sesbaniae & Sesbania sesban & Unknown & $867 \dagger$ \\
\hline$X$. a. tamarindi & Tamarindus indica & India & $869,955 \dagger$ \\
\hline X. a. vasculorum & $\begin{array}{l}\text { Saccharum officinarum, } \\
\text { Thysanolaena maxima }\end{array}$ & Australia, Mauritius & $895, \mathbf{8 9 9}, \mathbf{9 0 1 \dagger}, 903$ \\
\hline$X$. a. vesicatoria & $\begin{array}{l}\text { Capsicum sp., Lycopersicon } \\
\text { esculentum }\end{array}$ & Morocco, USA & $905,910,929 t 1$ \\
\hline X. a. vignaeradiatae & Vigna radiata & Sudan & $936 \dagger$ \\
\hline$X$. a. vignicola & Vigna unguiculata & India, Sudan, USA & $828,8139,8752 \dagger$ \\
\hline$X . a$. vitians & Lactuca sp. & Colombia, USA & $937 \dagger$ \\
\hline \multicolumn{4}{|l|}{ Group 10} \\
\hline X. oryzae oryzae & Oryza sativa & Philippines & $795, \mathbf{5 0 4 7}^{\mathrm{T}}, 6518$ \\
\hline$X$. o. oryzicola & Oryza sativa & Malaysia, Philippines & $665,793,797 \dagger$ \\
\hline \multicolumn{4}{|l|}{ Group 11} \\
\hline$X$. vasicola holcicola & Sorghum sp., Holcus sp. & New Zealand, USA & $736 \dagger, 7416,7489$ \\
\hline$X . v$. vasculorum & $\begin{array}{l}\text { Saccharum officinarum, Zea } \\
\text { mays }\end{array}$ & $\begin{array}{l}\text { Malagasy Republic, South } \\
\text { Africa }\end{array}$ & $900,902,8284$ \\
\hline \multicolumn{4}{|l|}{ Group 12} \\
\hline \multicolumn{3}{|l|}{ Group 13} & $847 \dagger$ \\
\hline X. melonis & Cucumis melo & Brazil & $8670 \dagger, 8672$ \\
\hline \multicolumn{4}{|l|}{ Group 14} \\
\hline $\begin{array}{l}X . \text { vesicatoria } \\
\text { Group } 15\end{array}$ & \multicolumn{2}{|c|}{ Group 15} & $911 \mathrm{t} 1 \dagger, 920 \mathrm{t} 1$ \\
\hline X. campestris aberrans & $\begin{array}{l}\text { Brassica oleracea L. var. } \\
\text { capitata L. }\end{array}$ & Australia & $9037 \dagger$ \\
\hline X.c. armoraciae & $\begin{array}{l}\text { Iberis sp., Armoracia } \\
\text { lapathifolia }\end{array}$ & Tanzania, USA & $535 \dagger, 7383 t 2$ \\
\hline X. c. barbareae & Barbarea vulgaris & USA & $547 \dagger, 7385$ \\
\hline X. c. campestris & $\begin{array}{l}\text { Brassica oleracea, Raphanus } \\
\text { sativus }\end{array}$ & $\begin{array}{l}\text { France, Malawi, Burundi, New } \\
\text { Zealand, UK }\end{array}$ & $\begin{array}{l}567, \mathbf{5 6 8}^{\mathrm{T}}, 571,573,583,7514, \\
8032\end{array}$ \\
\hline X.c. incanae & Matthiola sp. & USA & $7421,7490 \dagger$ \\
\hline X. c. raphani & Raphanus sativus & USA & $860 \uparrow, 7505,8134$ \\
\hline \multicolumn{4}{|l|}{ Group 16} \\
\hline$X$. translucens arrhenatheri & Arrhenatherum elatius & Switzerland & $727 t 1 \dagger$ \\
\hline$X . t$. cerealis & $\begin{array}{l}\text { Bromus inermis, Hordeum } \\
\text { vulgare }\end{array}$ & Canada, USA & $679 \dagger, 880$ \\
\hline$X . t$. graminis & $\begin{array}{l}\text { Lolium perenne, Dactylis } \\
\text { glomerata }\end{array}$ & Belgium, Switzerland & $713,726 \dagger$ \\
\hline$X . t$. hordei & $\begin{array}{l}\text { Hordeum vulgare, Dactylis } \\
\text { glomerata }\end{array}$ & $\begin{array}{l}\text { Canada, India, Japan, New } \\
\text { Zealand }\end{array}$ & $737 \dagger, 879, \mathbf{8 8 2}, \mathbf{8 2 7 9}$ \\
\hline$X . t . p h l e i$ & Phleum pratense & Belgium, Norway & $716,730 \dagger$ \\
\hline X.t.phleipratensis & Phleum pratense & USA & $843 \dagger$ \\
\hline X.t.poae & Poa trivialis & Switzerland & $594,728 \dagger$ \\
\hline$X . t$. secalis & Secale cereale & Canada & $\mathbf{8 8 3 \dagger}, 7507$ \\
\hline$X . t$. translucens & $\begin{array}{l}\text { Hordeum vulgare, Secale } \\
\text { cereale }\end{array}$ & USA & $\mathbf{8 7 6} \dagger, 5259,5260$ \\
\hline $\begin{array}{l}X . t . \text { undulosa } \\
\text { Group } 17\end{array}$ & Triticum sp. & Canada & $885,888, \mathbf{8 9 2} \dagger$ \\
\hline $\begin{array}{l}X . \text { hyacinthi } \\
\text { Group } \mathbf{1 8}\end{array}$ & Hyacinthus orientalis & The Netherlands & $739 \dagger, 742,8041$ \\
\hline $\begin{array}{l}\text { X. theicola } \\
\text { Group } 19\end{array}$ & Camellia sinensis & Japan & $8684 \dagger$ \\
\hline $\begin{array}{l}X \text {. sacchari } \\
\text { Group } \mathbf{2 0}\end{array}$ & Saccharum officinarum & Guadeloupe & 471,476 \\
\hline $\begin{array}{l}X \text {. albilineans } \\
\text { Group } 21\end{array}$ & Saccharum officinarum & Mauritius, Fiji & $842, \mathbf{4 9 4}^{\mathrm{T}}$ \\
\hline Stenotrophomonas maltophilia & Human with mouth cancer & Unknown & $\mathbf{9 5 8}^{\mathrm{T}}$ \\
\hline
\end{tabular}

* Strains indicated in bold were also used in AFLP analysis, strains in parentheses were not used in rep-PCR genomic fingerprinting. $\mathrm{t} 1, \mathrm{t} 2$ and $\mathrm{t} 3$ indicate several stable colony types.

$\dagger$ Pathovar reference strain. 


\section{INTRODUCTION}

Polyphasic taxonomy is increasingly being accepted as a comprehensive approach to microbial systematics (Colwell, 1970; Vandamme et al., 1996). However, the determination of total genomic DNA-DNA homology values has persisted as a dominant component of taxonomic analyses (Wayne et al., 1987; Murray et al., 1990). In fact, it has been referred to as the 'gold standard' for the definition of bacterial species (Stackebrandt \& Goebel, 1994), and 70 \% DNA-DNA homology values are considered to be the 'species limit' (Wayne et al., 1987; Murray et al., 1990). DNA-DNA homology-based approaches to classification are clearly impractical when analysing large collections of environmental isolates, due to the experimental limitations of analysing large numbers of strains by DNA-DNA reassociation methods in a pair-wise fashion. The analysis of $16 \mathrm{~S}$ or $23 \mathrm{~S}$ rDNA genes by DNA sequence analysis (Woese, 1987) or restriction enzyme digestion (ARDRA; Vaneechoutte et al., 1993) have become more useful approaches to assess the phylogenetic and taxonomic diversity of bacterial isolates (Heyndrickx et al., 1996; Moyer et $a l ., 1996)$. However, the power of rDNA-based protocols resides at a low phylogenetic or taxonomic level of resolution, which is valuable for classifying bacteria from the genus to even the kingdom level but which is insufficient to classify bacteria at the (sub)species level (Woese, 1987; Fox et al., 1992; Stackebrandt \& Goebel, 1994; Hauben et al., 1997). Therefore, we postulated that rapid molecular genomic fingerprinting methods would be valuable, high-resolution alternative approaches to the classification of bacteria, especially on the species-, subspecies- or strain-specific level (Louws et al., 1994, 1995, 1997; Janssen et al., 1996; Lin et al., 1996; Rademaker \& de Bruijn, 1997; Rademaker et al., 1997, 1998; Bragard et al., 1997).

Recently described genomic fingerprinting methods such as repetitive-sequence-based (rep)-PCR (Versalovic et al., 1991, 1994, 1998; de Bruijn, 1992), random amplified polymorphic DNA (RAPD) or DNA amplification fingerprinting (DAF) (Caetano-Anollés et al., 1991) and AFLP genomic fingerprinting (Vos et al., 1995) analyses have been suggested as accurate approaches to determine taxonomic and/or phylogenetic relationships between bacteria (Janssen et al., 1996; Huys et al., 1996; Clerc et al., 1998). However, the correlation between genomic fingerprinting and DNA-DNA homology studies has not been investigated on a sufficiently large scale to validate the former approaches as an alternative to, or a pre-screen precursor of, DNA-DNA homology-based bacterial speciation methods.

In this study, we chose the genus Xanthomonas as a model system to examine the relationship between phylogenetic relationships in bacteria based on DNADNA homology studies (Vauterin et al., 1995) and complemented by a variety of phenotypic methods (Vauterin et al., 1991, 1995, 1996; Yang et al., 1993) to those derived from genomic structure (fingerprinting) analyses based on rep-PCR or AFLP genomic fingerprinting approaches.

The rep-PCR-generated genomic fingerprints of 177 Xanthomonas strains, representing all 20 DNA-DNA homology groups (Vauterin et al., 1995), and one Stenotrophomonas maltophilia strain were employed to derive dendrograms of genetic relatedness using the GELCOMPAR program (Vauterin \& Vauterin, 1992). In addition, a subset of 80 Xanthomonas strains, representing the same 20 DNA-DNA homology groups, was analysed by AFLP analysis. On the basis of the results obtained, we suggest that the genomic structure of a bacterium, as deduced from its genomic fingerprint, represents an accurate reflection of its taxonomic and phylogenetic position based on total genomic DNA-DNA hybridization values.

\section{METHODS}

Bacterial strains. The 180 strains used in this study are listed in Table 1. Totals of 178 and 80 strains were selected for repPCR genomic fingerprinting and AFLP analysis, respectively (Table 1). The $S$. maltophilia type strain was included in the study as a control. The Xanthomonas strains selected comprise 20 genospecies and over 80 pathogenic variants, originating from 40 different countries (Table 1), and were obtained from the BCCM/LMG culture collection of the Laboratorium voor Microbiologie, Universiteit Gent, Ghent, Belgium.

DNA-DNA hybridization analysis. The global DNA-DNA homology matrix of 791 values, derived as described by De Ley et al. (1970) from the same 180 strains used for genomic fingerprinting, was obtained from Vauterin et al. (1995). Each DNA-DNA homology value represents the mean of between two and eight independent experiments (Vauterin et al., 1995).

Genomic fingerprinting. DNA was extracted from the bacterial strains as described by Rademaker \& de Bruijn (1997). BOX-PCR (based on primers targeting the highly conserved repetitive DNA sequences of the BOXA subunit of the BOX element of Streptococcus pneumoniae), ERICPCR (based on primers targeting the highly conserved enterobacterial repetitive intergenic consensus) and REPPCR (based on primers targeting the repetitive extragenic palindromic sequence) genomic fingerprints were obtained as described by Rademaker \& de Bruijn (1997) and Rademaker et al. (1998). AFLP fingerprints were generated as described by Janssen et al. (1996), using restriction enzymes EcoRI and TaqI and one 3' cytosine as selective base in both primers. Electrophoresis was performed in TBE buffer at $120 \mathrm{~W}$ and $50^{\circ} \mathrm{C}$ for $2 \mathrm{~h}$ (Janssen et al., 1996).

Computer-assisted analysis of genomic fingerprints. Computer-assisted analysis of the genomic fingerprints was performed by using the commercially available GELCOMPAR version 4.1 software program (Applied Maths) (Vauterin \& Vauterin, 1992), as described previously (Rademaker \& de Bruijn, 1997; Rademaker et al., 1997, 1999). Briefly, repPCR genomic fingerprints were analysed using a resolution of 400 and AFLP profiles of 1200 data points. Using the GELCOMPAR software, the similarity between pairs of separate or linearly combined BOX-, ERIC- and REP-PCR 
genomic fingerprints was calculated by using the productmoment correlation coefficient ( $r$ value; Pearson, 1926), applied to the whole densitometric curves of the gel tracks (Häne et al., 1993; Rademaker \& de Bruijn, 1997; Rademaker et al., 1999). Four full 178-by-178 similarity matrices of the respective rep-PCR fingerprints and one 80by-80 matrix of $r$ values for AFLP patterns were obtained (31 684 and 6400 values, respectively). Cluster analysis of the pairwise similarity values was performed by using the UPGMA (unweighted pair group method using averages) algorithm (Sneath \& Sokal, 1973).

Regression and other statistical analyses. The set of 791 DNA-DNA homology values derived from pairs of 180 strains (Vauterin et al., 1995) was compared with the similarities between pairs of AFLP and separate or linearly combined BOX-, ERIC- and REP-PCR genomic fingerprints generated from the same 180 strains. The resulting data were analysed by using the BioNumerics (Applied Maths) and SPSS 7.5 (SPSS Inc.) software packages. Productmoment and Kendall's tau correlation values, scatterplots and second-degree regression curve fits were obtained for each combination of genomic fingerprint similarity values $(r$ values) and the DNA-DNA homology values.

\section{RESULTS AND DISCUSSION}

The primary goal of this work was to determine whether clusters derived from genomic fingerprints corresponded to DNA-DNA homology-derived clusters and to determine the correlation between the primary similarity matrix values derived from genomic fingerprint patterns with actual DNA-DNA homology values (Fig. 1).

\section{Cluster analysis of rep-PCR genomic fingerprints versus DNA-DNA homology groupings}

First, BOX-, ERIC- and REP-PCR genomic fingerprints were generated from purified chromosomal DNA of 177 xanthomonad strains used previously for DNA-DNA hybridization experiments (Vauterin et al., 1995), including more than 80 pathovars of 20 genomic species and one strain classified as $S$. malto-

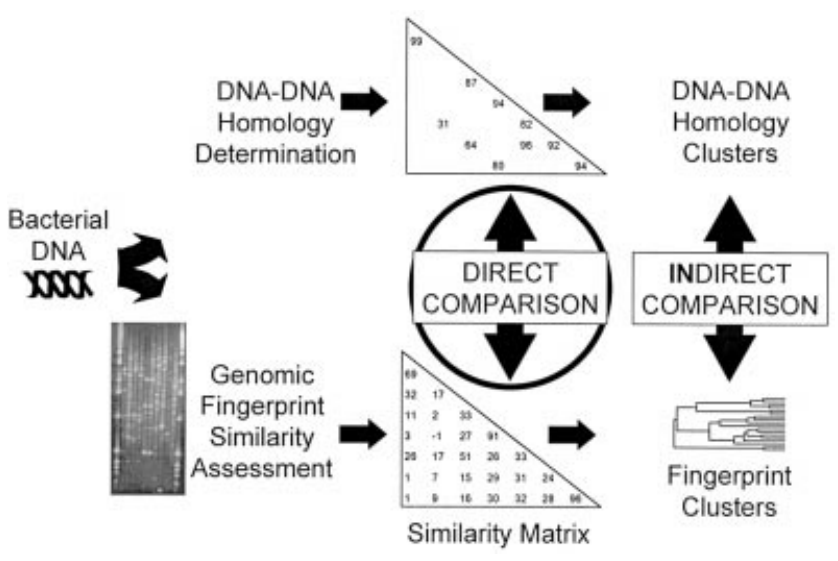

Fig. 1. Scheme illustrating direct and indirect comparison of genomic fingerprint analyses and DNA-DNA homology studies. philia (Table 1). The rep-PCR-amplified bacterial genomic fragments were resolved on agarose gels, resulting in complex fingerprint patterns with multiple bands of distinct intensities (Fig. 2). These patterns were analysed with the GELCOMPAR software package (Vauterin \& Vauterin, 1992), as described by Rademaker et al. (1999). Pearson's product-moment correlation $(r)$ values were calculated separately for the BOX-, ERIC- and REP-PCR genomic fingerprints and for the three linearly combined patterns (BOXERIC-REP; referred to as BER; Fig. 2). Twenty-five distinct and coherent clusters were observed after computer-assisted pattern analysis of the separate BOX-, ERIC- and REP-PCR genomic fingerprints and, to an even more precise extent, of the three linearly combined profiles (Fig. 2; boxes numbered 1 to $8,9-1$ to $9-6$ and 10 to 20 ). Groups $1-8$ and $10-20$ (Fig. 2) were found to correspond precisely to those identified by DNA-DNA homology studies (DNA homology groups 1-8 and 10-20; Vauterin et al., 1995).

Group 9 (Xanthomonas axonopodis), as identified by Vauterin et al. (1995), contains the strains of the collection with the lowest DNA-DNA homology values and was also found to be heterologous on the basis of rep-PCR genomic fingerprinting. Group 9 includes six genetic clusters on the basis of rep-PCR genomic fingerprints (9.1, 9.2 etc.; Fig. 2). Individual BOX-, ERIC- or REP-PCR genomic fingerprint data sets tended to group strains into similar subclusters with a few exceptions. A more detailed rep-PCR genomic fingerprinting analysis, using a much larger collection of strains from DNA-DNA homology group 9 , will be presented elsewhere.

\section{Cluster analysis of AFLP genomic fingerprints versus DNA-DNA homology groupings}

AFLP fingerprints were generated from 82 xanthomonad strains belonging to the collection of strains analysed by DNA-DNA homology studies (Vauterin et al., 1995) and rep-PCR genomic fingerprinting (this study), including the pathotype of each of the 20 genomic species (Table 1) and the $S$. maltophilia strain. The AFLP genomic fingerprint patterns obtained were found to be similar in complexity to the rep-PCRgenerated patterns (Fig. 3), and were analysed by using the GELCOMPAR software. Similarity values between the AFLP fingerprints were calculated. Subsequent cluster analysis yielded 24 groups, 19 of which corresponded to clusters identified by DNA-DNA homology studies (Fig. 3; boxes numbered 1 to 8, 9-1 to 95 and 10 to 20 ).

The AFLP clusters were found to be virtually identical to those generated by rep-PCR genomic fingerprinting (Figs 2 and 3). Strains classified within all but two DNA-DNA homology groups formed the same coherent clusters in AFLP and rep-PCR genomic fingerprinting analyses, the exceptions being DNA-DNA homology groups 9 and 4 . Strains classified within 


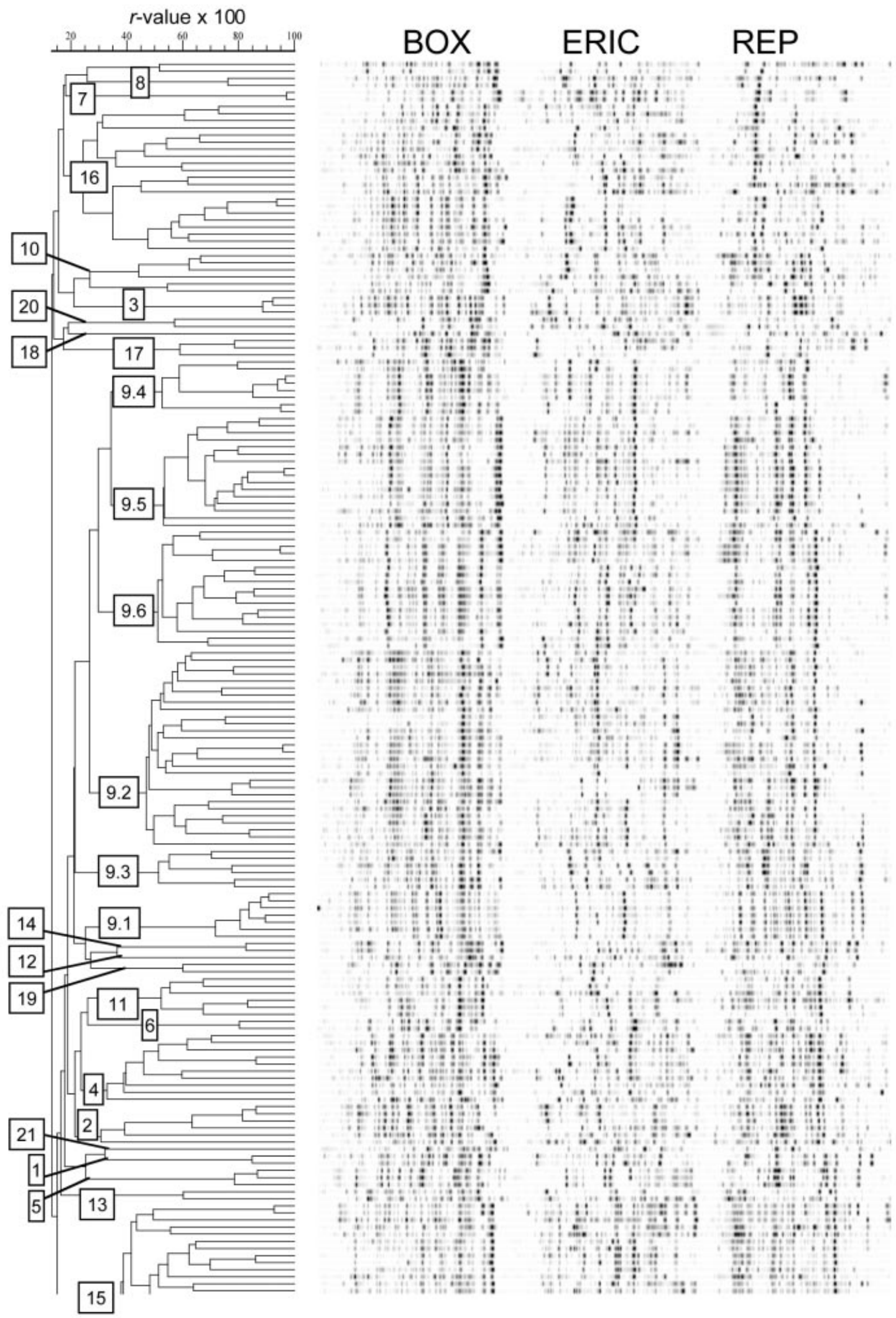

Fig. 2. UPGMA/product-moment cluster analysis of 178 linearly combined $B O X-$, ERIC- and REP-PCR-generated genomic fingerprints of the Xanthomonas strains listed in Table 1. The DNA-DNA homology groups are those determined by Vauterin et al. (1995) and subclusters within group 9 are as indicated. 


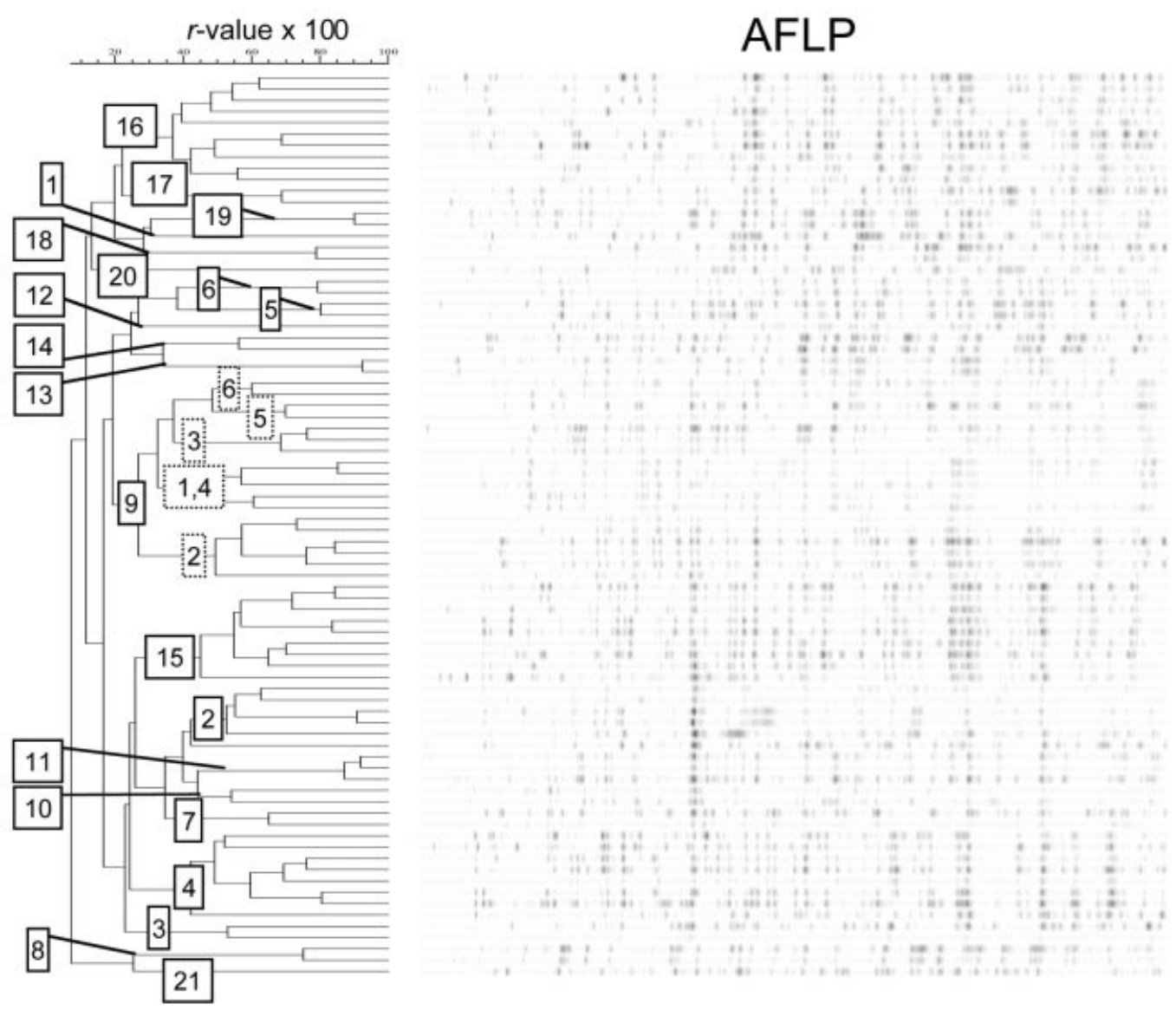

Fig. 3. UPGMA/product-moment cluster analysis of 80 AFLP genomic fingerprints of the Xanthomonas strains listed in Table 1. DNA-DNA homology groups (Vauterin et al., 1995) are shown. Moreover, subgroups of DNA-DNA homology group 9, as determined by rep-PCR genomic fingerprinting (see Fig. 2) are indicated in boxes with dotted lines.

DNA-DNA homology group 9 were found to be more similar to each other than to strains in any other group, but at a substantial lower level than within any other DNA-DNA homology group. Moreover, some of the subclusters found by AFLP analysis belonging to DNA-DNA homology group 9 corresponded to those observed by rep-PCR analysis (Figs 2 and 3; boxes numbered 9-1 to 9-6). Xanthomonas arboricola pv. populi strain LMG 12141 was separated from the other members of DNA-DNA homology group 4 in the cluster analysis of the AFLP patterns. This observation is supported by similar results obtained by analysing BOX-PCR fingerprinting patterns (data not shown; Rademaker et al., 1997).

\section{Correlation between similarity matrices using the product-moment correlation coefficient}

The topology of the dendrograms obtained by repPCR and AFLP genomic fingerprinting analyses was found to be in excellent agreement with the groups obtained by DNA-DNA homology studies. However, groupings derived from fingerprint similarity and DNA-DNA homology values could be regarded as 'secondary data', while similarity matrices derived from fingerprint patterns and initial DNA-DNA homology matrices constitute 'primary data', which are more suitable for direct comparison (Fig. 1). Therefore, a correlation study of the relevant primary data was carried out using the estimates of genetic similarity from rep-PCR or AFLP genomic fingerprints and DNA-DNA homology values as input.

First, the Pearson's product-moment correlation coefficient was employed, since it permitted a direct comparison of our results with those from other studies (see below). Subsequently, the non-parametric Kendall's tau coefficient was used.

Product-moment $(r)$ values were calculated between the DNA-DNA homology matrix and the corresponding similarity matrices of the respective genomic fingerprints from BOX-, ERIC- and REP-PCR-, BERand AFLP-based analyses (see above). A highly significant correlation was observed between the 
Table 2. Pearson's product-moment and non-parametric Kendall's tau correlation coefficients between and among the DNA-DNA homology matrix and similarity matrices of AFLP or rep-PCR genomic fingerprints

The observed correlation values are all significant at the $P=0.001$ level (two-tailed). $n$ is the number of values used in each analysis. DNA indicates the DNA-DNA homology matrix.

\begin{tabular}{|c|c|c|c|c|c|}
\hline Matrix & BOX & ERIC & REP & BER & AFLP \\
\hline \multicolumn{6}{|c|}{ Pearson's product-moment } \\
\hline ERIC & $0 \cdot 712$ & & & & \\
\hline REP & 0.774 & $0 \cdot 693$ & & & \\
\hline BER & 0.909 & $0 \cdot 849$ & $0 \cdot 890$ & & \\
\hline AFLP & $0 \cdot 722$ & $0 \cdot 680$ & $0 \cdot 713$ & $0 \cdot 781$ & \\
\hline DNA & 0.779 & $0 \cdot 669$ & $0 \cdot 777$ & $0 \cdot 808$ & $0 \cdot 838$ \\
\hline \multicolumn{6}{|c|}{ Kendall's tau } \\
\hline ERIC & $0 \cdot 404$ & & & & \\
\hline REP & $0 \cdot 478$ & $0 \cdot 374$ & & & \\
\hline BER & 0.670 & $0 \cdot 537$ & 0.625 & & \\
\hline AFLP & $0 \cdot 312$ & $0 \cdot 321$ & $0 \cdot 340$ & $0 \cdot 353$ & \\
\hline DNA & $0 \cdot 522$ & $0 \cdot 436$ & 0.549 & $0 \cdot 566$ & 0.522 \\
\hline \multicolumn{6}{|l|}{$n$} \\
\hline ERIC & 732 & & & & \\
\hline REP & 732 & 732 & & & \\
\hline BER & 732 & 732 & 732 & & \\
\hline AFLP & 294 & 294 & 294 & 294 & \\
\hline DNA & 732 & 732 & 732 & 732 & 322 \\
\hline
\end{tabular}

DNA-DNA homology matrix and corresponding fingerprint similarity matrices (Table 2). This comparison was carried out on the primary data, without interference or bias introduced by clustering methods or classification schemes. The observed correlations of fingerprint similarities with DNA-DNA homology values were found to be high and statistically significant $(P=0 \cdot 0001$, two-tailed test), ranging from 0.669 for ERIC to 0.838 for AFLP genomic fingerprint analyses.

The correlation between duplicate DNA-DNA homology series $(n=751)$ was found to be 0.942 , with the same level of significance $(P=0 \cdot 0001$; for a survey of the literature on experimental error in DNA-DNA pairing, see Hartford \& Sneath, 1990). The correlation of the combined BER fingerprint similarities with DNA-DNA homology values $(0 \cdot 808)$ was found to be higher than those found with individual BOX $(0 \cdot 779)$, ERIC (0.669) or REP (0.777) data sets. This probably reflects the larger number of fragments included in the pattern analysis of BER versus single fingerprints. It may also reflect a possible uneven distribution of BOX, ERIC or REP primer-annealing sites around bacterial genomes. It has been observed in Escherichia coli, for example, that ERIC and REP sequences can occur in clusters and that, in specific areas of the genome, too few closely arrayed ERIC or REP elements may be present to generate REP-element-toREP-element or ERIC-element-to-ERIC-element amplification products (Lupski \& Weinstock, 1992).

The high correlation observed when using the primary data was found to be in concordance with the corresponding topologies of the dendrograms (Figs 2 and 3 and data not shown). Correlation values between the rep-PCR fingerprinting methods ranged from 0.693 (ERIC/REP) to 0.909 (BOX/BER); $r$ values between AFLP and rep-PCR fingerprinting methods ranged from 0.680 (ERIC/AFLP) to 0.781 (BER/AFLP) (Table 2). This is in contrast with the results obtained by Gonzalez et al. (1998), who found a very low correlation value $(0 \cdot 15)$ between AFLP (four combinations) and RAPD (10 primers) fingerprinting of Colletotrichicum lindemuthianum. These authors excluded the possibility that their results were based on the complexity differences (number of bands) generated by the two fingerprinting techniques.

The high correlation we observed between rep-PCRgenerated and AFLP-based genomic fingerprinting results may be due to the fact that the different techniques are based on either naturally occurring repetitive elements or restriction sites, in contrast to RAPD analysis, which is based on the occurrence of random sequences that may have less biological significance. However, Clerc et al. (1998) found that genetic distance similarity values derived from RAPD data versus a simplified AFLP protocol (each with 12 primers) correlated well in a study of 'Pseudomonas tomato' strains $(r=0 \cdot 76)$. These authors reported that the two methods provided essentially the same results and are, therefore, both useful for exploring genetic diversity. They also concluded that AFLP analysis delineated genospecies more effectively than did RAPDs. Moreover, Clerc et al. (1998) suggested that the AFLP method but not the RAPD method could be used as a rapid and efficient alternative to DNA-DNA homology experiments to verify the nature of new isolates belonging to the genospecies ' $P$. tomato'.

\section{Correlation between similarity matrices using Kendall's tau coefficient}

The congruence between two different taxonomic or phylogenetic methods is traditionally estimated by using the Pearson product-moment correlation coefficient, which has some disadvantages. Firstly, the product-moment correlation only evaluates linear relationships. Therefore, a non-linear relationship (see Fig. 5) will lower the Pearson correlation, even if the relationship is without scatter of data points. The relationship between the similarity values of two different methods is often non-linear. Secondly, the Pearson correlation, being a parametric test, is very sensitive to the presence of outlying data points and, therefore, a few very aberrant data points can influence the final results substantially. Thirdly, the product moment is an inadequate statistical parameter for 


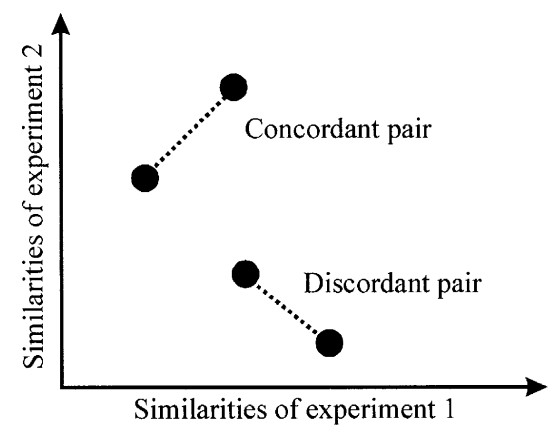

Fig. 4. Concordant and discordant pairs of similarity values (for explanation see text).

deciding whether the correlation is significant up to a certain confidence level. Unjustifiable assumptions may have to be made for the application of the product moment, e.g. that the data set follows a twodimensional Gaussian distribution function.

For these reasons, a non-parametric statistic is a valuable alternative. Here, we applied Kendall's tau coefficient (Kendall, 1970). This coefficient ranks and considers all possible pairs of similarity values and counts the number of concordant and discordant pairs. A pair is called concordant if both techniques agree upon the ordering of the similarities between the corresponding organisms and discordant if they do not (Fig. 4).

Kendall's tau value is defined as (concordant - discordant)/(concordant + discordant) values (Kendall, 1970). This value will be high (close to one) in the case of a positive relationship, positive meaning that both values are increasing in the same direction. Because it only involves the relative orderings of similarity values, it is relatively insensitive to 'outliers'. Moreover, the statistical significance of the relationship can be calculated directly without any further assumptions. The observed congruence of the genomic fingerprinting methods with DNA-DNA homology values using Kendall's tau coefficient was found to be highly significant $(P=0 \cdot 0001$, two-tailed test; Table $2)$. The closest relationships were observed when comparing DNA-DNA homology values with BER $(0.566)$ or REP $(0.549)$ genomic fingerprint similarity values. The comparison between AFLP or BOX-PCR fingerprint similarity and DNA-DNA homology values yielded a Kendall's tau coefficient of 0.522 (Table 2). The lowest Kendall's tau coefficient value $(0.436)$ was observed with ERIC-PCR genomic fingerprint similarities versus DNA-DNA homology values, as observed with the product moment coefficient (see above). Among genomic fingerprints, the lowest Kendall's tau value was found when comparing AFLP and rep-PCR fingerprint similarity matrices (Table 2 ). Among the individual rep-PCR fingerprint similarity matrices, the largest Kendall's tau coefficient $(0 \cdot 478)$ was observed when comparing REP- and BOX-PCR genomic fingerprint matrices.

\section{Regression analysis}

Since DNA-DNA homology values and genomic fingerprint similarity values between pairs of strains lead to highly similar groupings, we attempted to describe their relationship. While the previous section dealt with overall levels of correlation between the DNA-DNA homology matrix and genomic fingerprint similarity matrices and among the fingerprint similarity matrices, we also explored their specific relation.

DNA-DNA homology values were plotted against the product-moment-generated similarities between pairs of BOX-, ERIC- and REP-PCR, BER and AFLP genomic fingerprints (Fig. 5). A second-degree polynomial was fitted to the data, subject to the constraints of being monotonically increasing and passing through the $(100 \%, 100 \%)$ position. The relationships between DNA-DNA hybridization and each of the fingerprinting techniques were found to be comparable. The regression analysis highlighted important relationships among the different data sets (Fig. 5). For example, in the case of BOX-PCR-generated fingerprints, essentially all similarity $(r)$ values above $0 \cdot 5$ correlated well with DNA-DNA hybridization values of more then $50 \%, r$ values above 0.7 correlated with homology values above $70 \%$ and the product-moment values above 0.8 correlated with DNA-DNA homology values above $85 \%$ (Fig. 5a). The regression curves between DNA-DNA homology values and ERIC- or REP-PCR similarity values were found to be very similar to those obtained for BOX-PCR similarity values (curves not shown).

The relationship between DNA-DNA homology values and the $r$ values of BER analysis is shown in Fig. 5(b). The scatter in this plot is lower than that observed in plots of the individual rep-PCR fingerprint similarities and is, in fact, directly comparable with the fit between duplicate DNA-DNA homology values (data not shown). Essentially all BER fingerprint similarity values above 0.40 were found to correlate with DNA-DNA homology values exceeding $50 \%$, above 0.5 with values exceeding $70 \%$ and above 0.8 with values exceeding $90 \%$.

The relationship between DNA-DNA homology values and the $r$ values of AFLP fingerprints is shown in Fig. 5(c). In essence, AFLP similarity values above 0.50 correlated with DNA-DNA homology values exceeding $50 \%$, above 0.65 with values exceeding $70 \%$ and above 0.8 with values exceeding $85 \%$. The trend line for AFLP fingerprint similarities versus DNADNA homology values is based on a smaller number of data sets (322), but was still found to be comparable to the regression curves based on the collection of 732 similarity values (Table 2). Even an analysis of only 160 pairs of similarity values resulted in trend lines 
(a)

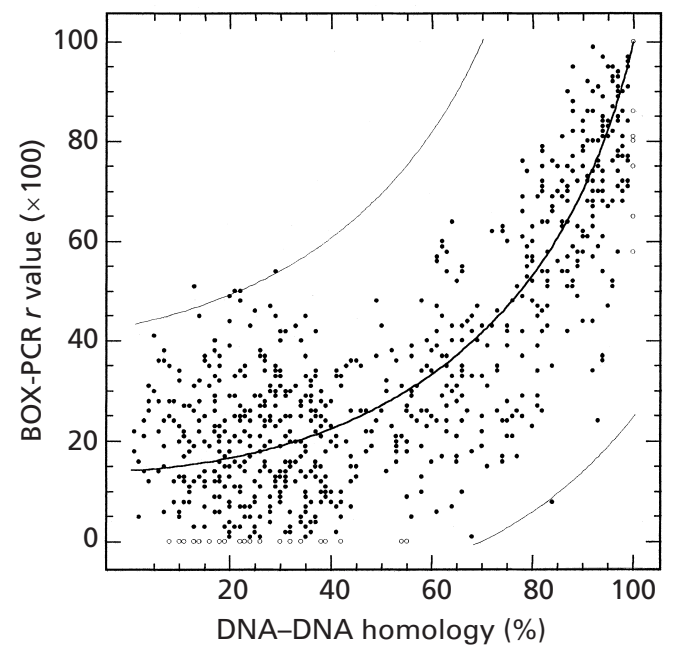

(c)

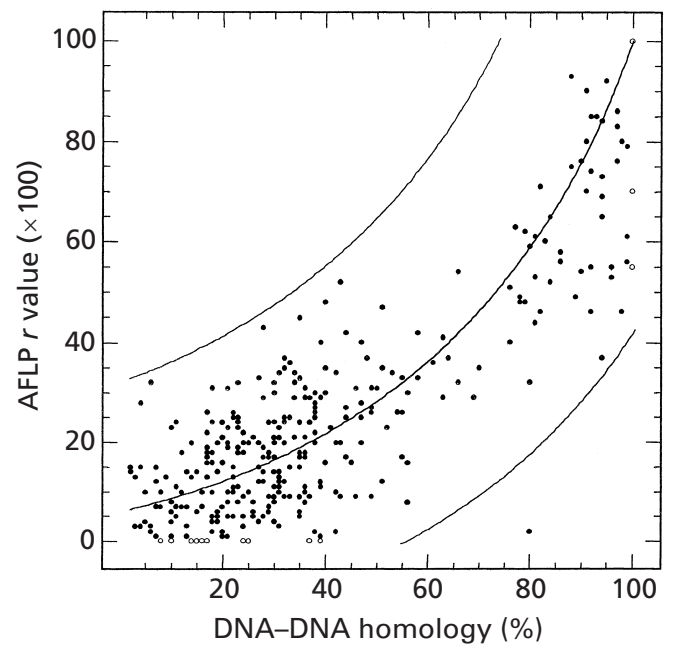

(b)

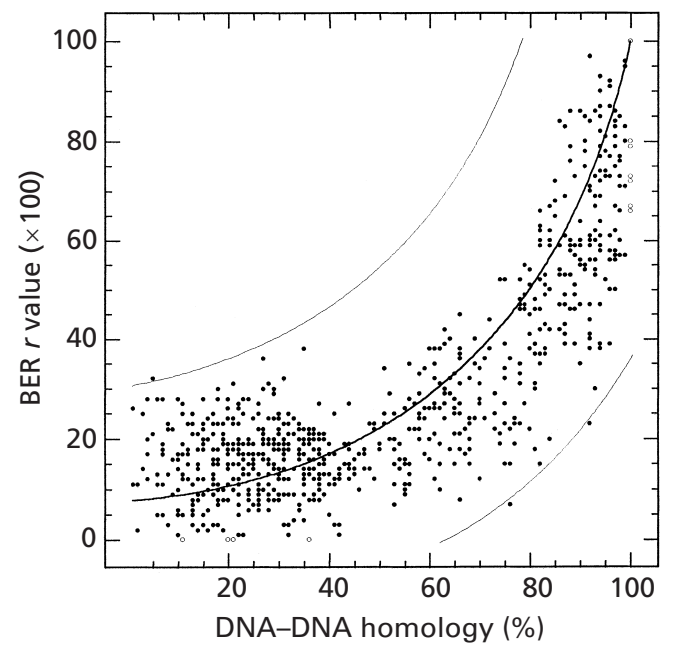

Fig. 5. Scatter plots of genetic similarities derived from rep-PCR and AFLP genomic fingerprint analyses and DNA-DNA homology studies. The relationships of DNA-DNA homology values (\%) to BOX-PCR (a), BER (b) and AFLP (c) genomic fingerprint product-moment similarities ( $r$ values) are indicated by second-degree regression curves. Confidence intervals are as indicated. The number of similarity values used is indicated in Table 2. essentially identical to those generated based on a larger number of similarity values, not only for AFLP but also for all rep-PCR fingerprint types presented here (data not shown).

The trend lines between the different genomic fingerprinting techniques were also determined (data not shown). The product-moment correlation between BER and the individual rep-PCR fingerprints was found to be high $(0.909,0.849$ and 0.890 for BER versus BOX-, ERIC- and REP-PCR fingerprints). The linear relationship was also found to have an intercept close to zero and a slope of approximately one, suggesting that the corresponding similarity values obtained from these data sets are almost identical. The lowest scatter was found with BOX-PCR fingerprint similarity values, supporting earlier observations that BOX-PCR may be the most robust of the three repPCR methods analysed here. The highest data point scatter was observed with ERIC-PCR fingerprint similarity values, which are more sensitive to disturbances.

\section{Conclusions}

rep-PCR- or AFLP-generated genomic fingerprint analyses yield results that are in close agreement with DNA-DNA homology studies, as determined by cluster analyses (indirect), as well as by direct comparison of primary similarity values. The observed high correlation between DNA-DNA homology studies and rep-PCR and AFLP genomic fingerprint analyses suggests that genomic fingerprint methods can function as core techniques in polyphasic taxonomy, regardless of the statistical model employed. The conclusion from the comparison of rep-PCR genomic fingerprinting with DNA-DNA homology studies is supported by the results of a smaller-scale study comparing rep-PCR genomic fingerprinting and 
dot-blot-mediated DNA-DNA homology studies (Nick et al., 1999). With regard to AFLP genomic fingerprinting versus DNA-DNA homology studies, our conclusions are also supported by other studies on a variety of bacteria (Huys et al., 1996; Janssen et al., 1996, 1997; Janssen \& Dijkshoorn, 1996; Clerc et al., 1998; Pedersen et al., 1998), although some controversy exists about this issue (Esteve, 1997).

Studies carried out by our laboratory and others on a variety of different bacterial genera and species have revealed that, at fine taxonomic resolution, phylogenetic trees derived from BOX-, ERIC- and REPPCR genomic fingerprinting are not always identical. This is to be expected, since different numbers of bands may be generated with each primer set, the annealing conditions vary between primers or sets, and the prevalence/distribution of the target repetitive elements in question may vary. A similar variation may occur with restriction-enzyme-dependent fingerprinting methods like RFLP, ARDRA and AFLP, depending on the restriction enzyme that is used. However, the phylogenetic 'trees' derived using each primer set separately are only slightly different. Moreover, our studies have shown that, regardless of the individual primer set used for rep-PCR genomic fingerprinting, the correlation of the phylogenetic trees with those derived from DNA-DNA homology studies is highly significant (Table 2). However, we want to emphasize here that the most highly significant and consistent results were obtained by combining the data obtained from BOX-, ERIC- and REP-PCR fingerprints (BER). This is logical, since the total number of data points (bands/peaks) is greatly increased. Moreover, the genome is more extensively covered, since certain regions may have more (properly spaced) copies of a particular element than others (Lupski \& Weinstock, 1992). Informative rep-PCR and/or AFLP genomic fingerprint patterns have been generated from all Gram-negative and several Grampositive bacteria analysed so far in studies that support our conclusions [see Versalovic et al. (1994) and Rademaker et. al. (1998) for lists of bacterial species tested]. To our knowledge, the Archaea have not yet been examined by rep-PCR genomic fingerprinting.

Similarities between genomic fingerprints, as well as DNA-DNA homology values, represent indirect measurements of sequence homologies and are dependent on the specific experimental conditions and analysis methods employed, and it is recognized that a hierarchy exists in terms of general applicability and standardization. Total DNA-DNA hybridization experiments are likely to be the most general, followed by AFLP and rep-PCR fingerprinting analyses. However, we stress in this paper that, in the bacterial species where significant comparative studies have been carried out, the results are comparable. Most important, however, is the applicability of the methods used to the analysis of large(r) collections of strains. There, an opposite (inverse) hierarchy exists, which demonstrates clearly that rep-PCR genomic fingerprinting is the least experimentally demanding and possibly the most discriminatory method of choice.

In any case, rep-PCR and AFLP genomic fingerprinting techniques appear to reflect the genotypic, phylogenetic and taxonomic relationships of organisms and, therefore, we propose that these genomic fingerprinting techniques can be used as a rapid means of determining taxonomic diversity and phylogenic structure, especially of large collections of bacterial isolates.

\section{ACKNOWLEDGEMENTS}

The development of the rep-PCR genomic fingerprinting method for the analysis of plant-associated and soil microbes has been supported by the DOE (DE FG 0290ER20021), the NSF Center for Microbial Ecology (DIR 8809640), Heinz, Roger Seeds and Procter \& Gamble and by the Consortium for Plant Biotechnology Research (DE - FC05-92OR22072) and the states of Michigan and North Carolina. We also gratefully acknowledge Maria Schneider, Jessica Wallace, Robert Jaros, Junko Yasuda (MSU), Lysiane Hauben, Sylvie VanEygen (RUG, Belgium) and Jim Lupski (Baylor College of Medicine, Houston) for technical support and many useful discussions on rep-PCR genomic fingerprinting.

\section{REFERENCES}

Bragard, C., Singer, E., Alizadeh, A., Vauterin, L., Maraite, H. \& Swings, J. (1997). Xanthomonas translucens from small grains: diversity and phylopathological relevance. Phytopathology 87 , 1111-1117.

de Bruijn, F. J. (1992). Use of repetitive (repetitive extragenic palindromic and enterobacterial repetitive intergenic consensus) sequences and the polymerase chain reaction to fingerprint the genomes of Rhizobium meliloti isolates and other soil bacteria. Appl Environ Microbiol 58, 2180-2187.

Caetano-Anollés, G., Bassam, B. J. \& Gresshoff, P. M. (1991). DNA amplification fingerprinting using very short arbitrary oligonucleotide primers. Biotechnology 9, 553-557.

Clerc, A., Manceau, C. \& Nesme, X. (1998). Comparison of randomly amplified polymorphic DNA with amplified fragment length polymorphism to assess genetic diversity and genetic relatedness within genospecies III of Pseudomonas syringae. Appl Environ Microbiol 64, 1180-1187.

Colwell, R. R. (1970). Polyphasic taxonomy of bacteria. In Culture Collections of Microorganisms, pp. 421-436. Edited by H. Iizuka \& T. Hasegawa. Tokyo: University of Tokyo Press.

De Ley, J., Cattoir, H. \& Reynaerts, A. (1970). The quantitative measurement of DNA hybridization from renaturation rates. Eur J Biochem 12, 133-142.

Esteve, C. (1997). Is AFLP fingerprinting a true alternative to the DNA-DNA pairing method to assess genospecies in the genus Aeromonas? Int $J$ Syst Bacteriol 47, 245-246.

Fox, G. E., Wisotzkey, J. D. \& Jurtshuk, P., Jr (1992). How close is close: 16S rRNA sequence identity may not be sufficient to guarantee species identity. Int J Syst Bacteriol 42, 166-170.

González, M., Rodríguez, R., Zavala, M. E., Jacobo, J. L., Hernández, F., Acosta, J., Martínez, O. \& Simpson, J. (1998). Characterization of Mexican isolates of Colletotrichum lindemuthianum by using differential cultivars and molecular markers. Phytopathology 88, 292-299.

Häne, B. G., Jäger, K. \& Drexler, H. G. (1993). The Pearson 
product-moment correlation coefficient is better suited for identification of DNA fingerprinting profiles than band matching algorithms. Electrophoresis 14, 967-972.

Hartford, T. \& Sneath, P. H. (1990). Experimental error in DNADNA pairing: a survey of the literature. $J$ Appl Bacteriol 68 , 527-542.

Hauben, L., Vauterin, L., Swings, J. \& Moore, E. R. B. (1997). Comparison of $16 \mathrm{~S}$ ribosomal DNA sequences of all Xanthomonas species. Int J Syst Bacteriol 47, 328-335.

Heyndrickx, M., Vauterin, L., Vandamme, P., Kersters, K. \& De Vos, P. (1996). Applicability of combined amplified ribosomal DNA restriction analysis (ARDRA) patterns in bacterial phylogeny and taxonomy. J Microbiol Methods 26, 247-259.

Huys, G., Coopman, R., Janssen, P. \& Kersters, K. (1996). Highresolution genotypic analysis of the genus Aeromonas by AFLP fingerprinting. Int J Syst Bacteriol 46, 572-580.

Janssen, P. \& Dijkshoorn, L. (1996). High resolution DNA fingerprinting of Acinetobacter outbreak strains. FEMS Microbiol Lett 142, 191-194.

Janssen, P., Coopman, R., Huys, G., Swings, J., Bleeker, M., Vos, P., Zabeau, M. \& Kersters, K. (1996). Evaluation of the DNA fingerprinting method AFLP as a new tool in bacterial taxonomy. Microbiology 142, 1881-1893.

Janssen, P., Maquelin, K., Coopman, R., Tjernberg, I., Bouvet, P. Kersters, K. \& Dijkshoorn, L. (1997). Discrimination of Acinetobacter genomic species by AFLP fingerprinting. Int $J$ Syst Bacteriol 47, 1179-1187.

Kendall, M. G. (1970). Rank Correlation Methods, 3rd edn. London: Charles Griffin.

Lin, J. J., Kuo, J. \& Ma, J. (1996). A PCR-based DNA fingerprinting technique: AFLP for molecular typing of bacteria. Nucleic Acids Res 24, 3649-3650.

Louws, F. J., Fulbright, D. W., Stephens, C. T. \& de Bruijn, F. J. (1994). Specific genomic fingerprints of phytopathogenic Xanthomonas and Pseudomonas pathovars and strains generated with repetitive sequences and PCR. Appl Environ Microbiol 60, 2286-2295.

Louws, F. J., Fulbright, D. W., Stephens, C. T. \& de Bruijn, F. J. (1995). Differentiation of genomic structure by rep-PCR fingerprinting to rapidly classify Xanthomonas campestris pv. vesicatoria. Phytopathology 85, 528-536.

Louws, F. J., Schneider, M. \& de Bruijn, F. J. (1997). Assessing genetic diversity of microbes using repetitive sequence-based PCR (rep-PCR). In Nucleic Acid Amplification Methods for the Analysis of Environmental Microbes, pp. 63-94. Edited by G. Toranzos. Lancaster, PA: Technomic Publishing.

Lupski, J. R. \& Weinstock, G. M. (1992). Short, interspersed repetitive DNA sequences in prokaryotic genomes. J Bacteriol 174, 4525-4529.

Moyer, C. L., Tiedje, J. M., Dobbs, F. C. \& Karl, D. M. (1996). A computer-simulated restriction fragment length polymorphism analysis of bacterial small-subunit rRNA genes: efficacy of selected tetrameric restriction enzymes for studies of microbial diversity in nature. Appl Environ Microbiol 62, 2501-2507.

Murray, R. G. E., Brenner, D. J., Colwell, R. R., De Vos, P., Goodfellow, M., Grimont, P. A. D., Pfennig, N., Stackebrandt, E. \& Zavarzin, G. A. (1990). Report of the ad hoc committee on approaches to taxonomy within the Proteobacteria. Int $J$ Syst Bacteriol 40, 213-215.

Nick, G., Jussila, M., Hoste, B., Niemi, M., Kaijalainen, S., de Lajudie, P., Gillis, M., de Bruijn, F. J. \& Lindström, K. (1999). Rhizobia isolated from root nodules of tropical leguminous tree characterized using DNA-DNA dot-blot hybridisation and repPCR genomic fingerprinting. Syst Appl Microbiol 22, 287-299.

Pearson, K. (1926). On the coefficient of racial likeness. Biometrika 18, 105-117.

Pedersen, K., Verdonck, L., Austin, B. and 9 other authors (1998). Taxonomic evidence that Vibrio carchariae Grimes et al. 1985 is a junior synonym of Vibrio harveyi (Johnson and Shunk 1936) Bauman et al. 1981. Int J Syst Bacteriol 48, 749-758.

Rademaker, J. L. W. \& de Bruijn, F. J. (1997). Characterization and classification of microbes by rep-PCR genomic fingerprinting and computer assisted pattern analysis. In $D N A$ Markers: Protocols, Applications and Overviews, pp. 151-171. Edited by G. Caetano-Anollés \& P. M. Gresshoff. New York: John Wiley.

Rademaker, J. L. W., Louws, F. J., Schultz, M. H., Rossbach, U., Vauterin, L., Swings, J. \& de Bruijn, F. J. (1997). Molecular systematics of xanthomonads by rep-PCR genomic fingerprinting and computer-assisted pattern analysis. Phytopathology 87, S81

Rademaker, J. L. W., Louws, F. J. \& de Bruijn, F. J. (1998). Characterization of the diversity of ecologically important microbes by rep-PCR genomic fingerprinting. In Molecular Microbial Ecology Manual, supplement 3, chapter 3.4.3, pp. 1-26. Edited by A. D. L. Akkermans, J. D. van Elsas \& F. J. de Bruijn. Dordrecht: Kluwer

Rademaker, J. L. W., Louws, F. J., Rossbach, U., Vinuesa, P. \& de Bruijn, F. J. (1999). Computer-assisted pattern analysis of molecular fingerprints and database construction. In Molecular Microbial Ecology Manual, supplement 4, chapter 7.1.3, pp. 1-33. Edited by A. D. L. Akkermans, J. D. van Elsas \& F. J. de Bruijn. Dordrecht: Kluwer.

Sneath, P. H. A. \& Sokal, R. R. (1973). Numerical Taxonomy. San Francisco: Freeman.

Stackebrandt, E. \& Goebel, B. M. (1994). Taxonomic note: a place for DNA-DNA reassociation and 16S rRNA sequence analysis in the present species definition in bacteriology. Int $J$ Syst Bacteriol 44, 846-849.

Vandamme, P., Pot, B., Gillis, M., de Vos, P., Kersters, K. \& Swings, J. (1996). Polyphasic taxonomy, a consensus approach to bacterial systematics. Microbiol Rev 60, 407-438.

Vaneechoutte, M., De Beenhouwer, H., Claeys, G., Verschraegen, G., De Rouck, A., Paepe, N., Elaichouni, A. \& Portaels, F. (1993). Identification of Mycobacterium species by using amplified ribosomal DNA restriction analysis. J Clin Microbiol 31, 2061-2065.

Vauterin, L. \& Vauterin, P. (1992). Computer-aided objective comparison of electrophoresis patterns for grouping and identification of microorganisms. Eur Microbiol 1, 37-41.

Vauterin, L., Swings, J. \& Kersters, K. (1991). Grouping of Xanthomonas campestris pathovars by SDS-PAGE of proteins. J Gen Microbiol 137, 1677-1687.

Vauterin, L., Hoste, B., Kersters, K. \& Swings, J. (1995). Reclassification of Xanthomonas. Int J Syst Bacteriol 45, 472-489.

Vauterin, L., Yang, P., Alvarez, A., Takikawa, Y., Roth, D. A., Vidaver, A. K., Stall, R. E., Kersters, K. \& Swings, J. (1996). Identification of non-pathogenic Xanthomonas strains associated with plants. Syst Appl Microbiol 19, 96-105.

Versalovic, J., Koeuth, T. \& Lupski, J. R. (1991). Distribution of repetitive DNA sequences in eubacteria and application to fingerprinting of bacterial genomes. Nucleic Acids Res 19, 6823-6831.

Versalovic, J., Schneider, M., de Bruijn, F. J. \& Lupski, J. R. (1994). 
Genomic fingerprinting of bacteria using repetitive sequence based PCR (rep-PCR). Methods Mol Cell Biol 5, 25-40.

Versalovic, J., de Bruijn, F. J. \& Lupski, J. R. (1998). Repetitive sequence-based PCR (rep-PCR) DNA fingerprinting of bacterial genomes. In Bacterial Genomes: Physical Structure and Analysis, pp. 437-454. Edited by F. J. de Bruijn, J. R. Lupski \& G. M. Weinstock. New York: Chapman \& Hall.

Vos, P., Hogers, R., Bleeker, M. and 8 other authors (1995). AFLP: a new technique for DNA fingerprinting. Nucleic Acids Res 23, 4407-4414.
Wayne, L. G., Brenner, D. J., Colwell, R. R. and 9 other authors (1987). Report of the ad hoc committee on reconciliation of approaches to bacterial systematics. Int $J$ Syst Bacteriol 37, 463-464.

Woese, C. R. (1987). Bacterial evolution. Microbiol Rev 51, 221-271.

Yang, P., Vauterin, L., Vancanneyt, M., Swings, J. \& Kersters, K. (1993). Application of fatty acid methyl esters for the taxonomic analysis of the genus Xanthomonas. Syst Appl Microbiol 16, 47-71. 